\title{
CES1 wt Allele
}

National Cancer Institute

\section{Source}

National Cancer Institute. CES1 wt Allele. NCI Thesaurus. Code C116035.

Human CES1 wild-type allele is located in the vicinity of $16 q 22.2$ and is approximately 31 $\mathrm{kb}$ in length. This allele, which encodes liver carboxylesterase 1 protein, is involved in the metabolism of xenobiotics and aromatic and aliphatic esters. Mutation of the gene is associated with Carboxylesterase 1 deficiency. 